\title{
AIR POLLUTANT UPTAKE BY SACRAMENTO'S URBAN FOREST
}

\author{
by Klaus I. Scott, E. Gregory McPherson, and James R. Simpson
}

\begin{abstract}
A dry deposition model was employed to estimate air pollutant uptake by Sacramento's urban forest. Assuming 1990 air pollutant concentrations, model simulations estimated that approximately 1,457 metric tons of air pollutant are absorbed annually, at an implied value of US $\$ 28.7$ million. The growing season daily uptake for ozone was approximately 2.4 metric tons per day, while particulate matter $\left(<10 \mu\right.$ diameter, $\mathrm{PM}_{10}$ ) uptake was slightly greater, at 2.7 metric tons per day. Daily uptake of $\mathrm{NO}_{2}$ and particulate matter represented $1 \%$ to $2 \%$ of anthropogenic emissions for the county. Estimated growing-season annual air pollutant uptake rates averaged $10.9 \mathrm{~kg} /$ (ha land area per yr) for the entire study area, $13.9 \mathrm{~kg} /$ (ha land area per $\mathrm{yr}$ ) for urban areas and $4.2 \mathrm{~kg} /$ (ha land area per $\mathrm{yr}$ ) for rural areas. Pollutant uptake rates decreased with decreasing tree canopy cover, along an urban-to-rural gradient.
\end{abstract}

Tree planting in Sacramento, California, and in other urban areas provides energy and air-quality benefits by direct shading of buildings (reducing energy demand for cooling), by cooling the atmosphere through transpiration of water from leaves, and by the direct absorption of air pollutants by leaf surfaces (Landsberg 1981; Akbari et al. 1992; Rosenfeld et al. 1995; Sailor 1995; McPherson et al. 1994, 1997a, 1997b; Simpson and McPherson 1996; Taha 1996; Simpson 1998). As urban forestry has expanded from the notion of municipal street tree management to urban ecosystem management, new partnerships among local government, electric utilities, and volunteer associations have formed. Local air-quality management districts represent a potential partner to the extent that healthy urban forests provide air-quality benefits. The aim of this research was to produce estimates of both annual air pollutant uptake by Sacramento's urban forest and its economic value. This study was one component of the Sacramento Urban Forest Ecosystem Study (SUFES), whose goal is to determine relationships between urban forest structure and function and associated benefits and costs. These and other SUFES results are being used as inputs for a geo-referenced cost-benefit analysis of the region's urban forest.

\section{Methods}

Overview. The Sacramento metropolitan area is a rapidly urbanizing region approximately $120 \mathrm{~km}$ (75 mi) northeast of San Francisco, located in California's Central Valley. The air basin is bounded on the east by the Sierra Nevada and on the west by the Coast Range mountains. Topography and meteorological conditions, combined with growing emissions, contribute to episodes of poor air quality. Summer months are warm and virtually cloud-free, with light winds, relative humidities less than $20 \%$, and days that can exceed $38^{\circ} \mathrm{C}\left(100^{\circ} \mathrm{F}\right)$ (NOAA 1990). Prevailing wind direction is southerly, except in spring and autumn, when it is northerly. During warm months, cool oceanic air often flows into the valley through a sealevel gap in the Coast Range, resulting in rapid cooling of the Sacramento area during late afternoon and nighttime hours.

Sacramento County air-quality monitors registered violations of federal ( $>0.12 \mathrm{ppm}$ ) and California ( $>0.09 \mathrm{ppm}$ ) standards for ozone $\left(\mathrm{O}_{3}\right)$ an annual average of 9 and 46 days, respectively, for the period 1990 through 1992 (ARB 1991, 1992, 1993). Federal and state laws allow no more than one event above the hourly standard ("exceedance") at any air monitoring site per year, averaged over 3 years. As a result, the Sacramento area has been designated a "nonattainment area" for both federal and state health-based standards for ozone. Ozone is formed in the atmosphere through photochemical reactions involving precursors such as oxides of nitrogen $\left(\mathrm{NO}_{\mathrm{x}}\right)$, hydrocarbon compounds, and oxygen. In 1990 estimated daily emission of $\mathrm{NO}_{\mathrm{x}}$ and hydrocarbons in Sacramento County was 90.9 and 129.0 t, respectively (SMAQMD 1994).

Particulate matter less than $10 \mu$ in diameter $\left(\mathrm{PM}_{10}\right)$ is generated by such processes as agricultural tillage, construction and demolition, road or vehicle wear, fuel combustion, and atmospheric photochemical reactions involving hydrocarbons, $\mathrm{NO}_{x}$, and oxides of sulfur. $\mathrm{Be}$ cause $\mathrm{PM}_{10}$ can readily enter respiratory airways, adverse health effects can occur from acute and chronic exposures. Federal and California standards for average daily and annual $\mathrm{PM}_{10}$ concentrations were exceeded in each year from 1990 to 1992. In 1990, estimated daily emission of $\mathrm{PM}_{10}$ in Sacramento County was 119 t per day (SMAQMD 1995).

Sulfur oxides $\left(\mathrm{SO}_{x}\right)$, such as sulfur dioxide $\left(\mathrm{SO}_{2}\right)$, are generated by combustion of sulfur-containing fuels, such as coal or fuel oil, and emitted principally from stationary sources such as electric utilities, smelters, and pulp and paper mills. Sulfur dioxide can be 
converted to sulfate aerosols such as sulfuric acid $\left(\mathrm{H}_{2} \mathrm{SO}_{4}\right)$, a component of acid deposition. Unlike many other urban regions, the Sacramento area has few significant stationary $\mathrm{SO}_{x}$ sources. Home heating-oil combustion and heavy-duty truck operation comprise the main $\mathrm{SO}_{2}$ sources for the county. In 1990, Sacramento County $\mathrm{SO}_{x}$ emissions were 4.2 t per day (SMAQMD, personal communication 1996) and ambient concentrations did not exceed either federal or state $\mathrm{SO}_{2}$ standards.

Trees absorb gaseous pollutants through leaf stomata and bind pollutant particles onto leaf surfaces. When trees absorb gaseous or intercept particulate pollutants without aid of precipitation, it is called "dry deposition." Deposited pollutant gases and particles can be chemically altered by plant tissues and may be metabolized or cause foliar injury (Smith 1978, 1981). Particles can be resuspended by turbulence or other mechanical action. Absorbed pollutants can be deposited to the ground surface as litter or leaf fall.

Air pollutant uptake by Sacramento's urban forest was estimated using canopy cover information from the SUFES project and dry deposition algorithms developed for regional air-quality models (Killus et al. 1984; Wesley 1989; Nowak 1994). Air pollutant deposition to buildings, streets, or other surfaces was neglected. To estimate pollutant uptake by trees, dry deposition model calculations incorporated information about air pollutant concentrations as well as meteorological and urban forest conditions. Hourly meteorological data and air pollutant concentrations, together with canopy cover areas from SUFES, were used as inputs. Model simulations were run for a season corresponding to the period when local deciduous trees are in leaf (March 15 through November 15). Hourly pollutant uptake for ozone $\left(\mathrm{O}_{3}\right)$, nitrogen dioxide $\left(\mathrm{NO}_{2}\right)$, sulfur dioxide $\left(\mathrm{SO}_{2}\right)$, and particulate matter $\left(\mathrm{PM}_{10}\right)$ were summed to yield total monthly and annual estimates of air pollutant removal by trees in the Sacramento area.

(For a complete description of the study area, sampling units, and land-use classes, see pages 175-177 of this issue.)
Emission-control cost factors (dollars per metric ton) were used to estimate economic value of air pollutant uptake by trees. Metric tons of pollutant removed by trees were multiplied by the control-cost factor for the particular pollutant species (Table 1). Control-cost factors were developed by the local air-quality management district (SMAQMD 1993) to determine cost effectiveness of pollutant emission-control technologies. Control-cost factors reflect what local regulators, industry, and other parties have determined to be society's willingness to pay for controlling precursor and pollutant emissions. We assigned the control-cost factor for $\mathrm{NO}_{2}$ to the value of ozone uptake by trees because direct control costs for ozone have not been defined (e.g., ozone is not directly emitted into the atmosphere).

Deposition. Dry deposition of an air pollutant to a forest can be expressed as the product of a deposition velocity $V_{d}(\mathrm{~cm} / \mathrm{s}$ or $\mathrm{m} / \mathrm{s})$, a pollutant concentration $\mathrm{C}$ $\left(\mathrm{g} / \mathrm{m}^{3}\right)$, the tree canopy coverage for a given land area $\left(\mathrm{m}^{2}\right)$, and a time step. When the canopy is treated as a single layer, the formulation is sometimes called a "big leaf" model. The deposition velocity is represented as an inverse sum of resistances, $V_{d}=1 /\left(r_{a}+r_{b}+r_{c}\right)$, where $r_{a}$ and $r_{b}$ are aerodynamic resistances, and $r_{c}$ is canopy resistance. Hourly deposition velocities for each pollutant were calculated for the Sacramento area for a base year (1990) growing season (March 15 through November 15) using formulations described in the appendix. Hourly meteorological data for wind speed, solar radiation, and precipitation from a California Department of Water Resources (CDWR) monitoring site in Sacramento County, together with nighttime 3hourly cloud cover data from a local airport, were used as input data. Hourly pollutant deposition to SubRAD (Sub-Regional Assessment District) canopy areas were then summed to obtain monthly and growing-season annual pollutant deposition.

Pollutant concentrations. Hourly concentrations for $\mathrm{NO}_{2}, \mathrm{O}_{3}$, and $\mathrm{SO}_{2}(\mathrm{ppm})$, and 24-hour average $\mathrm{PM}_{10}$ concentrations $\left(\mu \mathrm{g} / \mathrm{m}^{3}\right)$ were obtained from the U.S. EPA Aerometric Information Retrieval System (AIRS) database for 1990 for 10 monitoring stations throughout Sacramento County. One monitoring station was
Table 1. Pollutant uptake by trees ( $t$, metric tons) during the growing season and annual monetary value (in thousands of U.S. dollars) for Sacramento County sectors and entire study area. Estimated tons of pollutant removed by trees was multiplied by 1993 control costs $(\$ / t): \mathrm{O}_{3}=\$ 26,999 ; \mathrm{NO}_{2}=\$ 26,999 ; \mathrm{PM}_{10}=\$ 11,681 ; \mathrm{SO}_{2}=\$ 20,167$ (SMAQMD 1993).

\begin{tabular}{|c|c|c|c|c|c|c|c|c|c|c|}
\hline Sector & \multicolumn{2}{|c|}{ Ozone } & \multicolumn{2}{|c|}{$\mathrm{NO}_{2}$} & \multicolumn{2}{|c|}{$\mathrm{PM}_{10}$} & \multicolumn{2}{|c|}{$\mathrm{SO}_{2}$} & \multicolumn{2}{|c|}{ Total } \\
\hline City & 123.5 & 3,333 & 34.7 & 937 & 126.3 & 1,476 & 4.5 & 90 & 289.0 & 5,836 \\
\hline Rural & 261.8 & 7,070 & 54.7 & 1,476 & 338.1 & 3,949 & 14.2 & 287 & 668.8 & 12,782 \\
\hline Study area & 603.0 & 16,281 & 148.4 & 4,008 & 679.1 & 7,933 & 26.8 & 541 & $1,457.4$ & 28,763 \\
\hline
\end{tabular}

located in a rural area, whereas others were in urban areas of the county. Seven stations monitored for ozone, 6 for $\mathrm{NO}_{2}, 7$ for $\mathrm{PM}_{10}$, and 2 for $\mathrm{SO}_{2}$. Hourly ozone and $\mathrm{NO}_{2}$ concentrations averaged among monitoring 
stations in urban areas were used to estimate deposition to the city and suburban sectors. Ozone and $\mathrm{NO}_{2}$ concentrations from the rural monitoring station were used to estimate pollutant deposition to the rural sector. $\mathrm{PM}_{10}$ was monitored episodically (approximately one 24-hour period every 6 days) and on different days throughout the study area. Average monthly concentrations for the urban stations were used to estimate $\mathrm{PM}_{10}$ deposition to the city and suburban sectors, while average monthly concentrations from the single rural site were used to estimate particulate deposition to the rural sector. Sulfur dioxide was monitored in only 2 urban sites. Having no other option, we assumed $\mathrm{SO}_{2}$ to be homogeneously distributed throughout the study area.

Pollutant concentrations in Sacramento in 1990 were typical of concentrations for the period 1989 to 1992. For the growing season, $\mathrm{O}_{3}$ concentration between 1500 and 1600 hours averaged $0.061 \mathrm{ppm}$, with higher average hourly concentrations occurring in July (0.079 ppm), August (0.771 ppm), and September $(0.071 \mathrm{ppm})$. Lowest average hourly afternoon concentrations occurred in March (0.048 ppm) and November $(0.045 \mathrm{ppm})$. In Sacramento County, the 0.12 ppm National Ambient Air Quality Standard (NAAQS) for ozone was exceeded 15 times between June and September (ARB 1991). The growing-season $\mathrm{NO}_{2}$ concentrations averaged $0.017 \mathrm{ppm}$ in the morning hours and $0.023 \mathrm{ppm}$ in the afternoon. The average hourly concentrations were highest in October $(0.030,0.045$ ppm) and November (0.029, 0.044 ppm), occurring from 700 to 900 hours and from 1700 to 1900 hours. Monthly $\mathrm{PM}_{10}$ concentrations averaged $33 \mu \mathrm{g} / \mathrm{m}^{3}$, while peak concentrations during the growing season occurred in September $\left(39 \mu \mathrm{gm} /{ }^{3}\right)$, October $\left(44 \mu \mathrm{g} / \mathrm{m}^{3}\right)$, and November $\left(60 \mu \mathrm{g} / \mathrm{m}^{3}\right)$. The growing season average hourly $\mathrm{SO}_{2}$ concentration was low-0.001 ppm.

\section{Results and Discussion}

Total estimated pollutant uptake by Sacramento's urban forest was 1,457 metric tons $(t)(1 \mathrm{t}=1,000 \mathrm{~kg})$. Ozone and $P M_{10}$ had the highest removal rates (Table 1). Peak monthly removal rates for ozone occurred in April and May (83.2 and 83.8 t) and for $\mathrm{PM}_{10}$ in September and October (119.7 and $130.2 \mathrm{t}$ ). Average growing-season daily uptake for all pollutants combined was approximately 5.9 t per day, with ozone and $\mathrm{PM}_{10}$ at approximately 2.4 and $2.7 \mathrm{t}$ per day. Average daily uptake of $\mathrm{NO}_{2}$ was approximately 0.6 t per day, which is approximately $1 \%$ of the daily anthropogenic oxides of nitrogen emissions in Sacramento County (assuming $\mathrm{NO}_{x}$ is converted to $\mathrm{NO}_{2}$ ) (ARB 1995). Daily removal of $\mathrm{SO}_{2}(0.11 \mathrm{t} /$ day) and particulate matter by trees represented approximately $3 \%$ and $2 \%$ of the daily anthropogenic $\mathrm{SO}_{2}$ and $\mathrm{PM}_{10}$ emissions, respectively, for Sacramento County (ARB 1995).

Because daytime deposition velocities were greater in April than in August, maximum ozone uptake occurred in April, even though ozone concentrations were greater in August. Moderate daytime air temperatures in April $\left(-23^{\circ} \mathrm{C}\left[\sim 73^{\circ} \mathrm{F}\right]\right.$ compared to $32^{\circ} \mathrm{C}\left[90^{\circ} \mathrm{F}\right]$ in August) resulted in bulk canopy stomatal resistances $\left(r_{s}\right)$ of approximately $2.5 \mathrm{~s} / \mathrm{cm}$ from 1200 to 1500 hours, whereas the August daytime $r_{s}$ averaged $20.3 \mathrm{~s} / \mathrm{cm}$. Combined with other resistance components, bulk canopy resistance $\left(r_{c}\right)$ for April averaged $157.8 \mathrm{~s} / \mathrm{cm}$ from 1200 to 1500 hours, half that of the August $r_{c}$ $(248.3 \mathrm{~s} / \mathrm{cm})$. Resulting deposition velocities for ozone during the hours 1200 to 1500 ranged from 0.60 to $0.54 \mathrm{~cm} / \mathrm{s}$ in April (averaging $0.57 \mathrm{~cm} / \mathrm{s}$ ), a factor of 1.27 greater than deposition velocities in August $(0.48$ to $0.43 \mathrm{~cm} / \mathrm{s}$ ). For the same daytime period, April ozone concentrations $(\sim 0.049 \mathrm{ppm})$ were $16 \%$ lower than August ozone concentrations $(\sim 0.058 \mathrm{ppm})$. Taken together, these two factors account for much of the higher April uptake, compared to August. For example, ozone deposition to the city sector in April was approximately $15.9 \mathrm{t}$, whereas deposition in August was $14.7 \mathrm{t}(14.7 \mathrm{t} \times 1.27 \times 0.84 \approx 15.7 \mathrm{t})$.

Ozone and $\mathrm{NO}_{2}$ concentrations at the rural monitoring station were, on average, $19 \%$ and $29 \%$ lower, respectively, than concentrations in urban areas. As a result, deposition to the rural sector was slightly less than deposition to combined city and suburban sectors (Table 1), even though total canopy cover area was greater in the rural sector than combined city and suburban sectors (Table 2).

Annual $\mathrm{PM}_{10}$ deposition to combined city and suburban sectors (341 t) was nearly equivalent to deposition for the rural sector (338.1 t) (Table 1). Differences between monthly urban and rural $\mathrm{PM}_{10}$ concentrations used in deposition calculations were small for most of the growing season. However, in March the average hourly $\mathrm{PM}_{10}$ concentration for combined city and suburban sectors was $29 \mu \mathrm{g} / \mathrm{m}^{3}$ and in October the average was $52 \mu \mathrm{g} / \mathrm{m}^{3}$. Rural sector concentrations for these 2 months were 21 and $43 \mu \mathrm{g} / \mathrm{m}^{3}$, respectively. Because $\mathrm{PM}_{10}$ concentrations were roughly equivalent for much of the growing season, deposition to the rural sector could have been greater due to greater total canopy cover. However, lower surface roughness $z_{o}$ (Table A1; see appendix) in the rural area contributed to greater aerodynamic resistance, thereby reducing deposition velocities. For example, the October average hourly deposition velocity for particulates in the city sector between 1100 and 1700 hours was $1.3 \mathrm{~cm} / \mathrm{s}$ (suburban sector average was $1.2 \mathrm{~cm} / \mathrm{s}$ ), while the rural $V_{d}$ average was $1.1 \mathrm{~cm} / \mathrm{s}$. Hence, the 
Table 2. Tree canopy cover (ha, hectares) and growing-season air pollutant deposition ( $t$, metric tons) by land use for Sacramento County sectors and entire study area.

\begin{tabular}{|c|c|c|c|c|c|c|c|c|c|c|c|c|}
\hline \multirow[b]{2}{*}{ Land Use } & \multicolumn{3}{|c|}{ City } & \multicolumn{3}{|c|}{ Suburban } & \multicolumn{3}{|c|}{ Rural } & \multicolumn{3}{|c|}{ Study area } \\
\hline & ha & $\%^{w}$ & $t$ & ha & $\%^{x}$ & $t$ & ha & $\% y$ & $t$ & ha & $\%^{2}$ & $t$ \\
\hline Residential-Low & 1,725 & 56.1 & 162.0 & 3,475 & 60.7 & 303.4 & 748 & 7.3 & 48.8 & 5,948 & 31.2 & 514.3 \\
\hline Residential-High & 154 & 5.0 & 14.4 & 182 & 3.2 & 15.9 & 15 & 0.1 & 1.0 & 350 & 1.8 & 31.3 \\
\hline Comm./Indus. & 250 & 8.1 & 23.5 & 186 & 3.2 & 16.2 & 165 & 1.6 & 10.8 & 601 & 3.2 & 50.5 \\
\hline Institutional & 449 & 14.6 & 42.2 & 814 & 14.2 & 71.1 & 446 & 4.3 & 29.0 & 1,709 & 9.0 & 142.3 \\
\hline Transportation & 83 & 2.7 & 7.7 & 15 & 0.3 & 1.3 & 18 & 0.2 & 1.1 & 115 & 0.6 & 10.2 \\
\hline Agriculture & 21 & 0.7 & 2.0 & 82 & 1.4 & 7.2 & 2,559 & 24.9 & 166.8 & 2,662 & 14.01 & 75.9 \\
\hline Vacant/Wild & 396 & 12.9 & 37.2 & 967 & 16.9 & 84.5 & 6,310 & 61.5 & 411.3 & 7,673 & 40.35 & 33.0 \\
\hline Total & 3,078 & & 289.0 & 5,721 & & 499.6 & 10,26 & & 668.8 & 19,058 & & $1,457.4$ \\
\hline
\end{tabular}

$\overline{w, x, y}$ Calculated as the total canopy cover for a given land-use category, divided by the total canopy cover of the sector. ${ }^{z}$ Calculated as the total canopy cover for a given land-use category summed over city, suburban, and rural sectors, divided by the total canopy cover of the entire study area.

rural sector canopy cover advantage (factor $=1.16$ ) is nearly canceled out by decreased deposition velocities $\left(\right.$ factor $=1.3 / 1.1=1.18$ ). Slightly greater $P M_{10}$ deposition to combined city and suburban sectors may then be due to higher March and October $\mathrm{PM}_{10}$ concentrations.

Sulfur dioxide deposition to the rural sector was approximately $12 \%$ greater than deposition to urban sectors. Because $\mathrm{SO}_{2}$ was assumed to be homogeneously distributed throughout the study area, the difference in total deposition may be attributed to the greater overall canopy cover area in the rural sector $(10,261$ ha, Table 2$)$, offset by smaller deposition velocities due to greater aerodynamic resistance for the rural sector. Average hourly deposition velocities between 1100 and 1700 hours in April, when monthly $\mathrm{SO}_{2}$ uptake was greatest, for the city, suburban, and rural sectors were $0.46,0.44$, and $0.43 \mathrm{~cm} / \mathrm{s}$, respectively.

Total monetary value of pollutant removal (Table 1) was estimated to be US\$28.7 million $(\$ 1,500 /$ [ha tree cover per yr]). The highest value was for ozone removal $\left(57 \%\right.$ of the total value) followed by $\mathrm{PM}_{10}(27 \%)$. With an estimated 6 million trees in the Sacramento area (McPherson 1998), the annual air pollutant removal benefit is approximately $\$ 5$ per tree per year. Distribution of economic benefit by sector follows the distribution of pollutant deposition by canopy cover (Table 2). For example, due to higher pollutant concentrations in urban areas, monetary value of $\mathrm{NO}_{2}$ and ozone uptake is greater in combined city and suburban sectors than in the rural sector. On the other hand, economic values of $\mathrm{PM}_{10}$ uptake in the urban and rural sectors are comparable, while $\mathrm{SO}_{2}$ uptake is slightly greater in the rural sector due to greater canopy cover and assumed homogeneous distribution of $\mathrm{SO}_{2}$.

Pollutant deposition by land use. Over half of the tree cover in city and suburban sectors is located in the residential low-density land-use category (Table 2). Another $27 \%$ to $30 \%$ of the tree cover is in the institutional and vacant/wild categories (McPherson 1998). Consequently, it is estimated that over $80 \%$ of pollutant deposition to trees in city and suburban sectors occurs in these 3 land-use categories. Over half the tree cover in the rural sector is located in the vacant/wild category, with another $25 \%$ in agriculture. Similarly, the bulk of pollutant deposition to trees in the rural sector occurs in these land-use categories. It is not surprising that low-density residential areas in city and suburban sectors contain a large fraction of the sector's canopy cover. It is surprising that natural and unmanaged areas (e.g., vacant/wild) comprise another major portion of "urban" forest cover, nearly equal to that of institutional lands. This is because vacant/wild lands include riparian corridors, which are present along the American River and numerous creeks, streams, sloughs, and canals throughout the urbanized Sacramento area.

Normalizing total annual deposition to trees by land area results in deposition rates $(\mathrm{kg} /[$ ha per $\mathrm{yr}])$ by SubRAD, sector, or land use. The deposition rate reflects the distribution of canopy cover across land uses, as well as surface roughness and pollutant concentrations. Annual pollutant deposition rates by SubRAD and sector land use are shown in Figure 1 and Table 3.

Deposition rates are greatest in a transect from residential Sacramento city neighborhoods and along a northeast corridor between highways I-80 and US 50 . Estimated deposition rates in the city and suburban sectors are greatest in the residential lowdensity, residential high-density, and institutional landuse categories (Table 3). Although vacant/wild lands are areally extensive and contain between $13 \%$ and $17 \%$ of city and suburban canopy cover (Table 2), they are characterized by relatively open "oak savanna" 
woodlands (with the exception of riparian habitat). As a result, deposition rates for city and suburban sectors' vacant/wild lands are less than those of the more densely tree-covered residential and institutional land uses.

These estimated annual pollutant deposition rates are in agreement with simulations for other urban areas. For example, pollutant deposition rates for the Chicago, Illinois, area were estimated to range between 9.7 and $19.4 \mathrm{~kg} /$ (ha land area per yr) (Nowak 1994). For the Sacramento study area, deposition rates averaged $10.9 \mathrm{~kg} /$ (ha land area per yr). Estimated annual ozone deposition rate per ha of tree cover for the Sacramento area $(40.1 \mathrm{~kg} /[$ ha tree cover per yr]) was greater than the rate estimated for the Chicago study area $(30.7 \mathrm{~kg} /[$ ha tree cover per yr]) by a factor of 1.3 . Longer local foliation period and greater pollutant concentrations may contribute to the higher estimate for Sacramento. The growing season for Sacramento (246 days) exceeds Chicago's (May 1 through October 31, 184 days) by a factor of 1.3 . Summer daytime peak ozone concentrations for Sacramento averaged 0.061 ppm, a factor 1.4 greater than the Chicago average $(\sim 0.043 \mathrm{ppm})$. Taken together, pollutant uptake rates for the Sacramento area might be expected to exceed rates for the Chicago area by a factor of 1.8 (1.3 $\times$ 1.4). However, the hourly-varying daytime canopy resistances of the present model were somewhat greater than the constant values used in the Chicago study. Therefore, resulting deposition velocities with this model may be less than those computed using constant $r_{c}$ values. Extended foliation period and higher

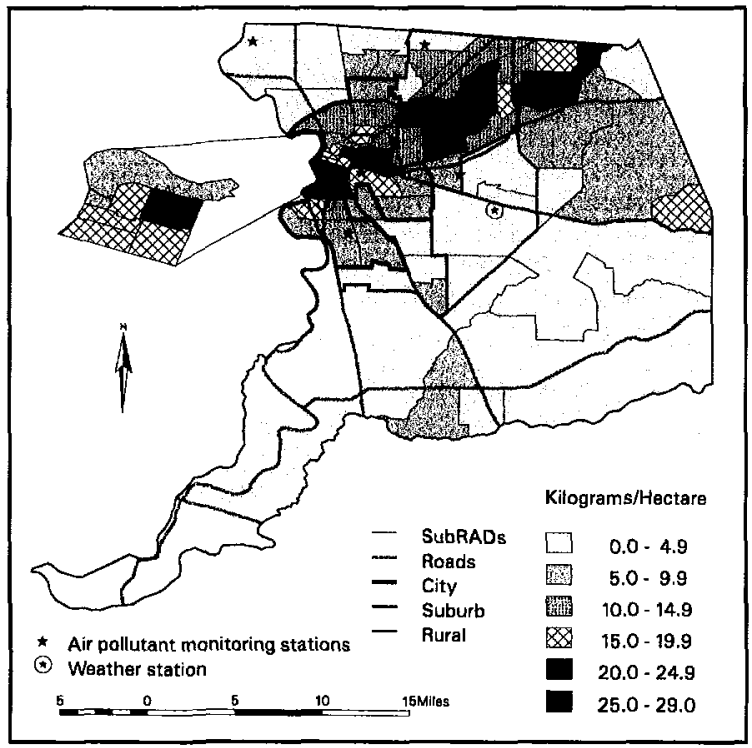

Figure 1. Estimated annual aìr pollutant uptake by Sacramento County's urban forest. pollutant concentrations could presumably result in greater deposition rates for urban forests in other regions, such as the Los Angeles, California, basin.

Due to differences in total canopy cover area, estimated total annual pollutant uptake for Sacramento $(1,457 \mathrm{t})$ is approximately $25 \%$ of that estimated for the Chicago study area $(5,575 \mathrm{t})$. Canopy cover for the Chicago study area was estimated at $19 \%$ of the $3,350 \mathrm{~km}^{2}$ land area (e.g., 65,000 ha), which is approximately a factor 3.4 greater than the estimated canopy cover for the Sacramento area $(19,000 \mathrm{ha})$. Although canopy cover and estimated total pollutant uptake are greater for the Chicago study area, the estimated monetary value of air pollutant uptake by trees in the Sacramento area (US\$28.7 million) is 3 times greater than Chicago's due to differences in control-cost pricing for the individual pollutants. For example, $\mathrm{PM}_{10}$ uptake by trees in the Chicago and suburban Cook County area $\left(2,479 \mathrm{~km}^{2}\right.$ [953 $\left.\mathrm{mi}^{2}\right]$, similar to the SUFES study area) was estimated at $1,391 \mathrm{t}$ for a value of $\$ 2$ million $(\$ 1,441 / t)$. By contrast, total $\mathrm{PM}_{10}$ uptake by trees in the SUFES study area $(679.1 \mathrm{t})$ is approximately half that for the Chicago and suburban Cook County area, but local control cost $(\$ 11,681 \mathrm{t})$ is 8.1 times greater. Taken together, the value of $\mathrm{PM}_{10}$ uptake ( $\$ 7.9$ million) by Sacramento trees is 4 times greater than the estimate for the Chicago and suburban Cook County area.

Sources of uncertainty and model limitations. Pollutant deposition estimates are sensitive to uncertainties associated with canopy resistance, particle resuspension rates, and inhomogeneities in the spatial distribution of air pollutants. Our use of canopy

Table 3. Air pollutant deposition rate (kg/[ha land area per yr]) by land use for Sacramento County sectors and entire study area.

\begin{tabular}{lrrrr}
\hline $\begin{array}{l}\text { Land } \\
\text { Use }\end{array}$ & \multicolumn{1}{c}{ City } & \multicolumn{1}{c}{ Suburban } & Rural & $\begin{array}{l}\text { Study } \\
\text { area }\end{array}$ \\
\hline Residential-Low & $18.6^{\mathrm{w}}$ & 17.4 & 5.1 & $14.4^{\mathrm{x}}$ \\
Residential-High & 14.2 & 10.6 & 5.5 & 11.7 \\
Comm./Indus. & 6.1 & 4.0 & 2.5 & 4.1 \\
Institutional & 14.8 & 21.8 & 4.0 & 10.6 \\
Transportation & 8.0 & 2.5 & 0.5 & 2.8 \\
Agriculture & 1.0 & 4.8 & 1.8 & 1.8 \\
Vacant/Wild & 9.0 & 9.5 & 5.1 & 5.7 \\
Sector & $12.2^{\mathrm{y}}$ & 13.5 & 3.4 & $5.7^{\mathrm{z}}$
\end{tabular}

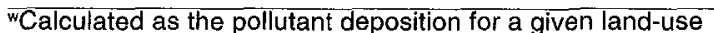
category, divided by the area of the land-use category. ${ }^{x}$ Calculated as the pollutant deposition for a given land-use category summed over city, suburban, and rural sectors, divided by the total area of the land-use category.

yCalculated as the total pollutant deposition in a given sector, divided by the total land area of that sector.

${ }^{2}$ Calculated as the total pollutant deposition for the entire study area, divided by the total land area. 
resistance for deciduous forests may overpredict daytime canopy resistance for well-watered urban trees. In the present model, bulk canopy stomatal resistance $\left(r_{s}\right)$ increases with temperature. However, leaf stomata of urban trees with abundant water sources may remain open, in contrast to natural forest stands, which may become water stressed. As a result, deposition to urban forests during warm periods might be underestimated. On the other hand, Massman et al. (1994) found that the Wesley algorithms underpredicted ozone canopy resistance for California Central Valley crops by a factor of 1.4 to 2 , which suggests possible overestimation of ozone deposition. An additional source of uncertainty associated with canopy resistance is local climate effects. In the present model, we have employed hourly meteorological data from a single station, which may not be representative of conditions in local atmospheric surface layers.

Other sources of uncertainty are canopy resistance parameter inputs based upon land use (Table A2; see appendix). By using parameters for deciduous forests, we have assumed that the urban forest has a closed canopy and is horizontally homogeneous at scales of several kilometers. Alternatively, urban forests may be better characterized as well-watered "sparse canopies," comprising patches or stands of trees, impervious surfaces (streets and buildings), turf, and dispersed, open-grown individual trees. Bulk canopy or surface resistances for urban forests are currently unavailable.

Factors that influence particulate dry deposition include atmospheric characteristics (e.g., turbulence), surface properties (e.g., canopy architecture, roughness, albedo, wetness, chemical reactivity), and properties of the depositing particle species (size, mass, chemical composition). Particle resuspension is also influenced by these factors (Davidson and Wu 1990). Based on limited literature for open-grown urban tree canopies (Dochinger 1980; Nowak 1994) we assumed a $50 \%$ resuspension rate as a base case. Resuspension rates may range from $20 \%$ (resulting in an underestimate by a factor of 1.6 from the base case) to $80 \%$ (causing an overestimate by a factor of 2.5 from the base case). In this model, we have assumed that $\mathrm{PM}_{10}$ deposition in the Sacramento area is comprised of relatively large particles, characteristic of fugitive dust from roads, construction, and agricultural activities. Smaller secondary aerosols $\left(\mathrm{PM}_{2.5}\right)$ are produced by photochemical reactions involving $\mathrm{NO}_{\mathrm{x}}, \mathrm{SO}_{\mathrm{x}}$, and hydrocarbons and comprise a significant portion of the overall mass of particulate pollution in urban areas. So-called process-oriented models, which treat particle removal processes as a function of particle size, will be required to model depo- sition of both $\mathrm{PM}_{10}$ and $\mathrm{PM}_{2.5}$ to urban forests, rather than the bulk-resistance-oriented model employed in this work (Ruijgrok et al. 1995).

Another source of uncertainty is the inhomogeneity of the pollutant field. Pollutant concentrations are influenced by such factors as prevailing winds and transport from nearby pollutant sources. Monitoring stations are generally located in populated areas to detect elevated concentrations or violations of ambient air-quality standards (ARB 1994). Extrapolation of monitoring station concentrations to distant canopy areas may then result in over estimations of pollutant dry deposition.

In this analysis, we applied the $\mathrm{NO}_{2}$ control cost to the value of ozone uptake by the urban forest. This method is problematic because it treats ozone as a primary pollutant and neglects photochemical reactions involved in the formation of ozone. In addition, biogenic hydrocarbon emissions from trees (BVOCs), not considered here, play a role in ozone formation (Corchnoy et al. 1992; Winer et al. 1995; Benjamin et al. 1996; Guenther et al. 1996). An alternative valuation scheme could involve estimating urban forest $B V O C$ emissions and adjusting associated BVOC emission cost with a correction factor representing a ratio of ozone uptake to ozone produced as a result of BVOC emissions. The interaction of urban forests with climate and photochemical air pollution has been investigated for the Atlanta, Georgia, and Los Angeles, California, metropolitan areas using photochemical and mesoscale meteorological models (Cardelino and Chameides 1990; Rosenfeld et al. 1995; Sailor 1995; Taha 1996). These efforts will benefit from improved algorithms for the representation of dry deposition to urban vegetation and the emission of BVOCs. Modeled BVOC emissions will also be influenced by a better understanding of urban forest canopy structure and the distribution of foliar biomass. By altering urban heat islands, urban forests may affect wind fields and convergence/divergence zones and thereby the distribution of both air pollutants and precipitation. In turn, by intercepting precipitation, urban forest canopies may alter stormwater runoff and water quality, as deposited pollutants drip or flow to the ground, in ways not explicitly treated in current urban hydrologic models (Xiao et al. 1998). Urban forests may then provide benefits for nonpoint-source water pollution and urban stormwater management.

\section{Summary}

A dry deposition model has been applied to estimate air pollutant deposition to Sacramento's urban forest. Assuming 1990 pollutant concentrations, approximately 1,457 t of air pollutants were absorbed by trees throughout the study area, at an implied value of US\$28.7 mil- 
lion. Pollutant uptake by trees represented $1 \%$ to $2 \%$ of anthropogenic emissions for such pollutants as $\mathrm{NO}_{x}$ and $\mathrm{PM}_{10}$. Urban land uses with the highest rates of pollutant uptake included residential areas, institutions (e.g., parks, campuses), and vacant, unmanaged, or natural areas. Furthermore, the institutional, commercial/industrial, and vacant/wild land uses for the city and suburban sectors also have high potential for additional tree planting (McPherson 1998). Unlike urban areas in the midwest or eastern United States, canopy cover in the Sacramento area decreases along an urban-to-rural gradient. Therefore, estimated pollutant uptake rates per unit land area were highest for residential and institutional land uses, compared to natural or unmanaged lands. Possible management implications of these estimates are that air pollutant uptake benefits from tree planting may be optimized by planting in areas where air pollutant concentrations are elevated and where relatively high planting densities can be achieved. Trees are an integral component of the complex web of roads, buildings, and waterways that comprise the urban ecosystem. Knowledge about their role in urban ecosystems will help to inform ecosystem management and enhance the health of urban dwellers.

\section{Literature Cited}

Air Resources Board. 1991. California Air Quality Data, Summary of 1990 Air Quality Data: Gaseous and Particulate Pollutants. TSD-91-006. California Environmental Protection Agency, Sacramento, CA.

Air Resources Board. 1992. California Air Quality Data, Summary of 1991 Air Quality Data: Gaseous and Particulate Pollutants. TSD-92-003. California Environmental Protection Agency, Sacramento, CA.

Air Resources Board. 1993. California Air Quality Data, Summary of 1992 Air Quality Data: Gaseous and Particulate Pollutants. TSD-93-003. California Environmental Protection Agency, Sacramento, CA.

Air Resources Board. 1994. California state and local air monitoring network plan. TSD-94-001. California Environmental Protection Agency, Sacramento, CA.

Air Resources Board. 1995. Emissions Inventory 1993. California Environmental Protection Agency, Sacramento, CA.

Akbari, H., S. Davis, S. Dorsano, J. Huang, and S. Winnett (Eds.). 1992. Cooling Our Communities: A Guidebook on Tree Planting and Light-Colored Surfacing. US Environmental Protection Agency, Washington, DC.

Baldocchi, D. D., B.B. Hicks and P. Camara. 1987. A canopy stomatal resistance model for gaseous deposition to vegetated surfaces. Atmos. Environ. 21:91-101.

Benjamin, M. T., M. Sudol, L. Bloch and A. M. Winer. 1996. Low-emitting urban forests: A taxonomic methodology for assigning isoprene and monoterpene emission rates. Atmos. Environ. 30:1437-1452.

Cardelino, C.A., and W. L. Chameides. 1990. Natural hydrocarbons, urbanization and urban ozone. J. Geophys. Res. 95:13971-13979.
Corchnoy, S.B., J. Arey, and R. Atkinson. 1992. Hydrocarbon emissions from twelve urban shade trees of the LOS Angeles, California, air basin. Atmos. Environ. 26B:339348.

Davidson, C.I., and Y.-L. Wu. 1990. Dry deposition of particles and vapors. pp. 103-216. In Lindberg, S.E., A.L. Page, and S.A. Norton (Eds.). Acidic Precipitation Volume 3: Sources, Deposition and Canopy Interactions. SpringerVerlag, New York, NY.

Dochinger, L.S. 1980. Interception of airborne particulates by tree plantings. J. Environ. Qual. 9:265-268.

Dyer, A.J., and C.F. Bradley. 1982. An alternative analysis of flux gradient relationships. Boundary-Layer Meteorol. 22:3-19.

Guenther, A.B., P. Zimmerman, L. Klinger, J. Greenberg, C. Ennis, K. Davis, W. Pollock, H. Westberg, G. Allwine, and C. Geron. 1996. Estimates of regional natural volatile organic compound fluxes from enclosure and ambient measurements. J. Geophys. Res. 101:1345-1359.

Gifford, F.A. 1976. Turbulent diffusion typing schemes: $A$ review. Nucl. Saf. 17:71.

Golder, D. 1972. Relations among stability parameters in the surface layer. Boundary-Layer Meteorol. 3:47-58.

Killus, J.P., J. Meyer, D. Durran, G. Anderson, T. Jerskey, S. Reynolds, and J. Ames. 1984. Continued research in mesoscale air pollution simulation modeling. Volume 5 , Refinements in numerical analysis, transport, chemistry and pollutant removal. EPA/600/3-84/095a. US Environmental Protection Agency, Research Triangle Park, NC.

Landsberg, H.E. 1981. The Urban Heat Island. Academic Press, New York, NY.

Lettau, Heinz H. 1969. Note on aerodynamic roughness parameter estimation on the basis of roughness element description. J. Appl. Meteorol. 8: 828-832.

Massman, W.J., J. Pederson, A. Delany, D. Grantz, G. den Hartog, H.H. Neumann, S.P. Oncley, R. Pearson, Jr., and R.H. Shaw. 1994. An evaluation of the regional acid deposition model surface module for ozone uptake at three sites in the San Joaquin Valley of California. J. Geophys. Res. 99:8281-8294.

McPherson, E.G., D.J. Nowak, and R.A. Rowntree (Eds.). 1994. Chicago's Urban Forest Ecosystem: Results of the Chicago Urban Forest Climate Project. USDA For. Serv. Northeast. For. Exp. Sta. Gen. Tech. Rpt. NE-186. Radnor, PA.

McPherson, E.G., D.J. Nowak, G. Heisler, S. Grimmond, C. Souch, R. Grant, and R.A. Rowntree. 1997a. Quantifying urban forest structure, function, and value: The Chicago Urban Forest Climate Project. Urban Ecosys. 1:49-61.

McPherson, E.G., K.I. Scott, and J.R. Simpson. 1997b (in press). Cost effectiveness of residential yard trees for improving air quality in Sacramento, California. Atmos. Environ.: Urban Atmospheres.

McPherson, E.G. 1998. Structure and sustainability of Sacramento's urban forest. J. Arboric. 24(4):174-190.

Myrup, L.O. and D. L. Morgan. 1972. Numerical Model of the Urban Atmosphere, Vol. 1: The City-Surface Interface. Contributions in Atmospheric Science No. 4. Univ. Calif., Davis, CA. 
National Oceanic and Atmospheric Administration. 1990. Local Climatological Data, Annual Summary with Comparative Data: Sacramento, CA. ISSN 0198-0963. National Climatic Data Center, Asheville, NC.

Nowak, D.J. 1994. Air pollution removal by Chicago's urban forest, pp 63-82. In McPherson, E.G., D.J. Nowak, and R A. Rowntree (Eds.). Chicago's Urban Forest Ecosystem: Results of the Chicago Urban Forest Climate Project. USDA For. Serv. Northeast. For. Exp. Sta. Gen. Tech. Rpt. NE-186. Radnor, PA.

Rosenfeld, A.H., H. Akbari, S. Bretz, B.L. Fishman, D.M. Kurn, D. Sailor, and H. Taha. 1995. Mitigation of urban heat islands: Materials, utility programs, updates. Energy Build. 22:255-265.

Ruijgrok, W., C.I. Davidson, and K.W. Nicholson. 1995. Dry deposition of particles: Implications and recommendations for mapping of deposition over Europe. Tellus. 47B:587-601.

Sacramento Metropolitan Air Quality Management District. 1993. BACT Cost Analysis Policy Document. Sacramento, CA.

Sacramento Metropolitan Air Quality Management District. 1994. Post-1996 Rate of Progress Plan for Ozone. Sacramento, CA.

Sacramento Metropolitan Air Quality Management District. 1995. 1995 Attainment and Maintenance Plan for the Federal PM 10 Standard. Sacramento, CA.

Sailor, D.J. 1995. Simulated urban climate response to modifications in surface albedo and vegetative cover. $\mathrm{J}$. Appl. Meteorol. 34:1694-1704.

Simpson, J.R., and E.G. McPherson. 1996. Potential of tree shade for reducing residential energy use in California. J. Arboric. 22(1):10-18.

Simpson, J.R. 1998. Urban forest impacts on regional cooling and heating energy use: Sacramento County case study. J. Arboric. 24(4):201-214.

Smith, W.H. 1978. Urban vegetation and air quality, pp 284305. In Proceedings of the National Urban Forestry Conference. ESF Publication 80-003. College of Environmental Science and Forestry, State Univ. New York, Syracuse, NY.

Smith, W.H. 1981. Air Pollution and Forests: Interactions Between Air Contaminants and Forest Ecosystems. Springer-Verlag, New York, NY.

Taha, H. 1996. Modeling impacts of increased urban vegetation on ozone air quality in the South Coast Air Basin. Atmos. Environ. 30:3423-3430.

van Ulden, A.P., and A.A.M. Holtslag. 1985. Estimation of atmospheric boundary layer parameters for diffusion application. J. Climate Appl. Meteorol. 24:1196-1207.

Wesley, M.L. 1989. Parameterization of surface resistances to gaseous dry deposition in regional-scale numerical models. Atmos. Environ. 23:1293-1304.

Winer, A.M., L. Chinkin, J. Arey, R. Atkinson, J. Adams, and J. Karlik. 1995. Critical Evaluation of a Biogenic Emission System for Photochemical Grid Modeling in California. Final Report, California Air Resources Board, Contract No. 93-725. School of Public Health, Univ. Calif., Los Angeles, CA.
Xiao, Q.F., E.G. McPherson, J.R. Simpson, and S.L. Ustin. 1998. Rainfall interception by Sacramento's urban forest. J. Arboric. 24(4):235-244.

\section{Appendix: Summary of the Dry Deposition Model}

Dry deposition is defined as the product of a deposition velocity $V_{d}(\mathrm{~cm} / \mathrm{s}$ or $\mathrm{m} / \mathrm{s})$, a pollutant concentration $\mathrm{C}(\mathrm{g} /$ $\mathrm{m}^{3}$ ), canopy area $\left(\mathrm{m}^{2}\right)$, and a time step (Killus et al. 1984; Nowak 1994). By analogy with Ohm's Law, deposition velocity is defined as the inverse sum of a series of resistances, $V_{d}=1 /\left(r_{a}+r_{b}+r_{c}\right)$, where $r_{a}$ is aerodynamic resistance, $r_{b}$ is quasi-laminar boundary-layer resistance, and $r_{c}$ is the canopy resistance (Baldocchi et al. 1987). Aerodynamic resistance, $r_{a}$, is expressed as

$$
r_{a}=\frac{u(z)}{u_{*}^{2}}
$$

where $u(z)$ is the wind speed $(\mathrm{m} / \mathrm{s})$ at height $z$ (defined as $10 \mathrm{~m}$ above a zero-plane displacement length, e.g., $z-d=10)$, and $u_{s}$ is the frictional velocity $(\mathrm{m} / \mathrm{s})$. Resistance $r_{b}$ is expressed as

$$
r_{b}=B^{-1} u_{*}^{-1}
$$

where $B^{-1}=2.2_{*}^{-1 / 3}$ The frictional velocity $u_{*}(\mathrm{~m} / \mathrm{s})$ is

$$
u_{*}=\frac{k u(z-d)}{\ln \left[\frac{(z-d)}{z_{0}}\right]-\Psi_{m}\left[\frac{(z-d)}{L}\right]+\Psi_{m}\left[\frac{z_{0}}{L}\right]}
$$

where $\Psi_{m}$ is the dimensionless stability function for momentum, $k$ is von Karman's constant $(0.4), d$ is a zeroplane displacement length, $z_{o}$ is an aerodynamic roughness length for the 3 sectors (city, suburban, rural), and $L$ is the Monin-Obukhov length $(\mathrm{m})$ (van Ulden and Holtslag 1985). L was estimated by classifying hourly meteorological data (solar radiation, wind speed, nighttime cloud cover) using an automated look-up table to estimate $1 / L$ as a function of Pasquill classes (Golder 1972; Gifford 1976). Nine stability classes were used. When atmospheric conditions are unstable $(L \leq 0)$, the function $\Psi_{m}$ (van Ulden and Holtslag 1985) is

$$
\begin{aligned}
& L \leq 0: \\
& \Psi_{m}=2 \ln \left[\frac{(1+X)}{2}\right]+\ln \left[\frac{\left(1+X^{2}\right)}{2}\right]-2 \tan ^{-1}(X)+\frac{\pi}{2}
\end{aligned}
$$

where the dimensionless $X$ (Dyer and Bradley 1982) is

$$
X=\left(1-28 \frac{z}{L}\right)^{0.25}
$$

When conditions are stable $(L>0)$, the function $\Psi_{m}$ (van Ulden and Holtslag 1985) is 


$$
\begin{aligned}
& L>0: \\
& \Psi_{m}=-17\left[1-\exp \left(-0.29 \frac{(z-d)}{L}\right)\right]
\end{aligned}
$$

Surface morphology from SUFES was used to estimate surface roughness $\left(z_{0}\right)$ for each sector by land use. Land use was determined through aerial photo interpretation and ground sampling. Tree dimensions were determined from SUFES measurements of trees within 675 randomly distributed $100 \mathrm{~m}^{2}$ plots (McPherson 1998). The formulation of Lettau (1969) was used to estimate surface roughness due to trees:

$$
z_{o}=c_{2} h \lambda
$$

where $c_{2}$ is a constant $(\approx 0.5), h$ is an average height of roughness elements (trees) in the area of interest (e.g., sector land use), and $\lambda$ is a roughness density, defined as a ratio of average silhouette area of obstacles in the area of interest to average lot area. Average lot area is defined as the quotient of total area over which the elements are being considered (e.g., sector land use), divided by the number of elements within the area of interest. Tree height and crown silhouette area were determined from measurements taken of trees located in the plots. Tree silhouette area was calculated using formulas for cylindrical, paraboloid, and ellipsoid crown geometries. Building roughness values for Sacramento land-use categories were adapted from Myrup and Morgan (1972). Sector composite roughness values were derived by selecting the greatest of 2 values of roughness length $z_{o}$ (buildings or trees) and weighting the selected value by the corresponding land use area percentage (Table A1).

Canopy or surface resistance $\left(r_{c}\right)$ was parameterized following formulations of Wesley (1989) as

$$
r_{c}=\left[1 /\left(r_{s}+r_{m x}\right)+1 / r_{l u x}+1 /\left(r_{d c}+r_{c l x}\right)+1 /\left(r_{a c}+r_{g s x}\right)\right]^{-1}
$$

Bulk canopy stomatal resistance $r_{s}$ is represented as

$$
r_{s}=r_{i}\left(1+\left[200(G+0.1)^{-1}\right]^{2}\right)\left(400\left[T_{s}\left(40-T_{s}\right)\right]^{-1}\right)
$$

where $r_{i}$ is a minimum stomatal resistance for water vapor, $G$ is solar radiation $\left(\mathrm{W} / \mathrm{m}^{2}\right)$, and $T_{s}$ is the air temperature near the surface $\left({ }^{\circ} \mathrm{C}\right.$ ) between $0^{\circ} \mathrm{C}$ and $40^{\circ} \mathrm{C}$. Bulk canopy stomatal resistance is set to a large value when temperatures are outside this range, based on the assumption that stomatal uptake is reduced. At nighttime, bulk canopy stomatal resistance is also set to a large value.

A combined minimum stomatal and mesophyll resistance for a pollutant gas $x$ is represented as

$$
r_{s m x}=r_{s} \frac{D_{H_{2} O}}{D_{x}}+r_{m x}
$$

where $D_{x}$ is the molecular diffusivity of pollutant gas $x$ in air, $D_{\mathrm{H}_{2} \mathrm{O}}$ is the molecular diffusivity of water vapor, and $r_{m x}$ is the mesophyll resistance for the gas of interest.

The mesophyll resistance for gas $x$ is computed as

$$
r_{m x}=\left(H^{*} / 3000+100 f_{0}\right)^{-1}
$$

where the parameter $H^{*}$ is an effective Henry's Law constant, and $f_{0}$ is a reactivity factor. The 2 parameters represent parallel diffusion pathways to extracellular water within leaf stomata and are used to scale the uptake rates. Parameters $H^{*}$ and $f_{0}$ are also used in expressions for the resistances $r_{f u x^{\prime}} r_{c \mid x^{\prime}}$ and $r_{g s x^{\prime}}$. The resistance $r_{l u x}$ represents outer surfaces of the upper canopy. Deposition pathways to leaves and stems in the subcanopy are represented by $r_{c \mid x}$. Deposition to the "ground" surface (e.g., leaf litter, soil) is represented by $r_{a c}$ and $r_{g s x}$. Resistances $r_{i t u x}, r_{c l x}$ and $r_{g s x}$ are computed as

$$
\begin{gathered}
r_{l u x}=r_{l u}\left(10^{-5} H^{*}+f_{0}\right)^{-1} \\
r_{c l x}=\left[H^{*} /\left(10^{5} r_{c l s}\right)^{+} f_{0} / r_{c l o}\right]^{-1} \\
r_{g s x}=\left[H^{*} /\left(10^{5} r_{g s S}\right)^{+} / f_{0} / r_{g s o}\right]^{-1}
\end{gathered}
$$

where $r_{c I O}, r_{c I S}, r_{g s O}$, and $r_{g S S}$ are reference resistances corresponding to those for $\mathrm{O}_{3}$ and $\mathrm{SO}_{2}$.

Buoyant convection and slope effects in plant canopies are represented by the resistance $r_{d c}$ given by

$$
r_{d c}=100\left[1+1000(G+10)^{-1}\right](1+1000 \theta)^{-1}
$$

where $\theta$ (radians) is the slope of the local terrain. In the present model, we let $\theta=1.66 \times 10^{-3}$, representing a transect extending from a National Weather Service observing station just south of the downtown area to an air pollutant monitoring station $28.2 \mathrm{~km}$ (10.8 mi) to the northeast. Input parameters and resistances are listed in Table A2.

Canopy resistance for particles $\left(\mathrm{PM}_{10}\right)$ was estimated based upon an average deposition velocity minus an average $r_{a}$ and $r_{b}$. In a field experiment of particle interception by open-grown tree stands, Dochinger (1980) reported resuspension rates ranging from $20 \%$ to $80 \%$. For trees in Sacramento, a $50 \%$ resuspension rate was chosen as a midvalue. Particle interception by evergreen trees and deciduous tree stem surfaces during fall and winter months was neglected. Hourly deposition velocities for each pollutant were calculated using estimates for $r_{a}, r_{b}$, and $r_{c}$. Deposition velocities were set equal to zero during periods of precipitation (the CDWR monitoring station registered approximately $137.2 \mathrm{~mm}$ (5.4 in.) of precipitation during the growing season). 
Acknowledgments. The authors thank Coe Owen (US Environmental Protection Agency, Region 9), Mark Ott (Sacramento Metropolitan Air Quality Management District), and Jim Goodridge (California Department of Water Resources), who provided air quality and meteorological data. Thanks also to William Massman (USDA-Forest Service) and Bruce Jackson (California Air Resources Board), who reviewed earlier versions of this manuscript.
USDA Forest Service

Pacific Southwest Research Station

clo Department of Environmental Horticulture

University of California

Davis, CA 95616

Table A1. Surface roughness $\left(z_{o}\right)$ due to buildings and trees, for sectors by land use.

\begin{tabular}{|c|c|c|c|c|c|c|c|c|c|c|}
\hline & \multirow[b]{2}{*}{$\begin{array}{l}\text { Bldgs } \\
\text { only }\end{array}$} & \multicolumn{3}{|c|}{ City } & \multicolumn{3}{|c|}{ Suburban } & \multicolumn{3}{|c|}{ Rural } \\
\hline & & $\begin{array}{l}\text { Land } \\
\text { area }\end{array}$ & $\begin{array}{l}\text { Trees } \\
\text { only }\end{array}$ & Selected & $\begin{array}{l}\text { Land } \\
\text { area }\end{array}$ & $\begin{array}{l}\text { Trees } \\
\text { only }\end{array}$ & Selected & $\begin{array}{l}\text { Land } \\
\text { area }\end{array}$ & $\begin{array}{l}\text { Trees } \\
\text { only }\end{array}$ & Selected \\
\hline Land use & $Z_{o}(m)$ & $\%$ & $Z_{0}(m)$ & $Z_{0}(m)$ & $\%$ & $Z_{o}(m)$ & $Z_{0}(m)$ & $\%$ & $Z_{0}(m)$ & $Z_{o}(m)$ \\
\hline$A G$ & 0.02 & 10.7 & 0.00 & 0.02 & 1.5 & 0.00 & 0.02 & 42.5 & 0.00 & 0.02 \\
\hline $\mathrm{Cl}$ & 0.25 & 14.0 & 0.51 & 0.51 & 10.3 & 0.30 & 0.30 & 4.2 & 0.10 & 0.25 \\
\hline IN & 0.08 & 16.0 & 1.04 & 1.04 & 15.6 & 0.35 & 0.35 & 5.5 & 2.88 & 2.88 \\
\hline $\mathrm{RH}$ & 1.20 & 5.4 & 3.42 & 3.42 & 6.1 & 1.54 & 1.54 & 0.1 & 0.00 & 1.20 \\
\hline RL & 0.36 & 38.6 & 1.98 & 1.98 & 51.2 & 0.86 & 0.86 & 6.5 & 0.25 & 0.36 \\
\hline TR & 0.04 & 6.1 & 0.02 & 0.04 & 1.4 & 0.00 & 0.04 & 1.1 & 0.00 & 0.04 \\
\hline VW & 0.02 & 9.3 & 0.26 & 0.26 & 13.9 & 0.94 & 0.94 & 40.1 & 0.78 & 0.78 \\
\hline Composite & & & & 1.21 & & & 0.75 & & & 0.51 \\
\hline
\end{tabular}

Table A2. Input parameter values for canopy resistance.

\begin{tabular}{|c|c|c|c|c|c|c|c|}
\hline$(\mathrm{s} / \mathrm{m})$ & $r_{i}$ & $r_{t u}$ & $r_{a c}$ & $r_{g s S}$ & $r_{g s O}$ & $r_{C I S}$ & $r_{c 10}$ \\
\hline Input resistances & 70 & 2000 & 2000 & 500 & 200 & 2000 & 1000 \\
\hline & & $\mathrm{O}_{3}$ & & $\mathrm{NO}_{2}$ & & $\mathrm{SO}_{2}$ & \\
\hline $\begin{array}{l}D_{\mathrm{H}_{2 \mathrm{O}}} / \mathrm{Dx} \\
\mathrm{H}^{\star} \\
f\end{array}$ & & $\begin{array}{l}1.6 \\
0.01 \\
1\end{array}$ & & $\begin{array}{l}1.6 \\
0.01 \\
0.1\end{array}$ & & $\begin{array}{l}1.9 \\
1 \times 10^{5} \\
0\end{array}$ & \\
\hline
\end{tabular}

$f_{0} \quad$ minimum stomatal resistance for water vapor.

$r_{i j} \quad$ upper canopy, outer surface resistance.

$r_{a c} \quad$ resistance due to canopy height, density.

$r_{g s s}$ resistance to $\mathrm{SO}_{2}$ uptake at the ground surface.

$r_{\text {gso }} \quad$ resistance to $\mathrm{O}_{3}$ uptake at the ground surface.

$r_{a S} \quad$ resistance to $\mathrm{SO}_{2}$ uptake in lower canopy.

resistance to $\mathrm{O}_{3}$ uptake in lower canopy.

$\mathrm{D}_{\mathrm{H}_{2} \mathrm{O}} / \mathrm{D}_{\mathrm{x}}$ ratio of molecular diffusivities for water vapor and gas " $\mathrm{x}$ ".

$\mathrm{H}^{{ }^{2} \mathrm{O}}$ effective Henry's Law values for water with near-neutral $\mathrm{pH}$.

$f_{0} \quad$ reactivity factor. 
Résumé. Un modèle de déposition des poussières a été employé pour estimer la quantité de polluants atmosphériques captés par la forêt urbaine de Sacramento. En se basant sur les concentrations de polluants atmosphériques de 1990, les simulations avec le modèle ont permis d'estimer qu'approximativement 1457 tonnes métriques de polluants sont absorbées annuellement, soit une valeur implicite de $\$ 28,7$ millions. Durant la saison de croissance, il se capte quotidiennement 2,4 tonnes métriques en ozone alors que pour les poussières il est de 2,7 tonnes. Le captage quotidien en $\mathrm{NO}_{2}$ et $P M_{10}$ représente 1 à $2 \%$ des émissions totales dans le comté. Les taux moyens annuels de captage des poussières durant la saison de croissance sont estimés à $10,9 \mathrm{~kg} / \mathrm{ha}$ de terrain par an pour le territoire entier, à $13,9 \mathrm{~kg} / \mathrm{ha}$ par an pour les zones urbaines et à 4,2 $\mathrm{kg} / \mathrm{ha}$ par an pour les zones rurales. La distribution spatiale des taux de captage des polluants décroît avec la densité du couvert arboré des zones urbanisées vers les zones rurales. Les conséquences sur la gestion de l'aménagement des forêts urbaines en regard de la qualité de l'air sont discutées.

Zusammenfassung. Um die Aufnahme von Luftverunreinigungen zu schätzen, wurde ein Modell eingesetzt, welches die Verunreinigungen im Trockenverfahren aufnimmt. Unter Voraussetzung einer Luftverschmutzungskonzentration 1990, ergab die Modellsimulation eine jährliche Aufnahme von schätzungsweise 1,457 t mit einme Wert von ca US $\$ 28,7$ Millionen. Die Tägliche Ozonaufnahme während der Wachstumsperiode betrug ca. 2,4 t pro Tag, während die Aufnahme von festen Teichen etwas größer (2,7 pro Tag) war. Die tägliche Aufnahme von $\mathrm{NO}_{2}$ und ${ }_{P M} 10$ repräsentiert 1-2 \% der Emissionsmessungen für den Bezirk. Die geschätzte jährliche Aufnahme von Luftverunreingungen während der Wachstumperiode betrug durchschnittlich 10,9 $\mathrm{kg} \mathrm{ha}^{-1}$ Landfläche $\mathrm{yr}^{-1}$ für die ganze Studienfläche, $13,9 \mathrm{~kg}$ $\mathrm{ha}^{-1}$ Landfläche $\mathrm{yr}^{-1}$ für die bewohnten Gebiete und 4,2 $\mathrm{kg}$ $\mathrm{ha}^{-1}$ Landfläche $\mathrm{yr}^{-1}$ für ländliche Regionen. Die räumliche Verteilung der Aufnahme von Verunreiningungen nahm mit der Dichte der Baumkronen entlang des Gradienten von Stady zu Land ab. Hier werden Anforderungen bei der Planung von Stadtforsten zur Verbessserung von Luftqualität diskutiert.

Resumen. Se emplea un modelo de deposición seca para estimar la absorción de la polución del aire por el bosque urbano de Sacramento. Asumiendo las concentraciones de polutantes del aire de 1990, las simulaciones estiman que aproximadamente 1,457 toneladas métricas de polutantes del aire son absorbidas anualmente, con un valor implicado de US $\$ 28,7$ millones. La absorción diaria en la estación de crecimiento para ozono fue aproximadamente 2.4 toneladas métricas por d'a mientras que las part'culas materiales fueron levemente mayores, en 2.7 toneladas métricas por d'a. La absorción diaria de $\mathrm{NO}_{2}$ y $\mathrm{PM}_{10}$ representó 1 a $2 \%$ de los inventarios de emisiones para el condado. Las tasas estimadas en la estación de crecimiento anual de la absorción de polutantes del aire promediaron $10.9 \mathrm{~kg} \mathrm{ha}^{-1}$ área de terreno año-1 para el total del área de estudio, 13.9 $\mathrm{kg} \mathrm{ha}^{-1}$ área de terreno año-1 para áreas urbanizadas y 4.2 $\mathrm{kg} \mathrm{ha}^{-1}$ área de terreno año-1 para áreas rurales. La distribución espacial de las tasas de absorción de polutantes disminuyó con la densidad de la cobertura del dosel de los árboles en el gradiente urbano-rural. Se discuten las implicaciones de manejo en la planeación del bosque urbano para mejorar la calidad del aire. 